\title{
Androstenedione, dehydroepiandrosterone and testosterone in ovarian vein plasma and androstenedione in peripheral arterial plasma during the bovine oestrous cycle
}

\author{
T. H. Wise*, D. Caton $\dagger$, W. W. Thatcher $\ddagger$, A. Rami Lehrer§ and \\ M. J. Fields \\ Departments of Animal Science, $₫$ Dairy Science and $†$ Obstetrics and Gynecology, \\ University of Florida, Gainesville, Florida 32611, U.S.A. and \\ $\S$ Division of Animal Reproduction, The Volcani Center, P.O. Box 6, Bet Dagan, Israel
}

\begin{abstract}
Summary. Catheters were placed in the carotid artery via a facial artery $(n=12)$ and in the ovarian vein $(n=12)$, and, in conjunction, electromagnetic flow meters were placed around the ovarian artery $(n=6)$ in cyclic beef cows. Androstenedione was quantitatively the highest and dehydroepiandrosterone the lowest of the ovarian androgens measured. Ovarian androgens were correlated positively with each other $(P<0.05)$ but not with ovarian blood flow or day of the cycle. There was a trend for spikes of androgen release (ovarian vein concentration $\times$ ovarian blood flow) from the ovary to be greatest during the period of decreasing progesterone and CL regression. However, only with testosterone were spikes of release different (Days -13 to $-9<$ Days -8 to $-4 ; P<0.05$; Day $0=$ oestrus). The dynamic changes in ovarian androgens noted in this study were compatible with the concept of continuous follicular development and atresia throughout the oestrous cycle.
\end{abstract}

\section{Introduction}

Androgens appear to be involved in the regulation of follicular growth (Louvet, Harman, Schreiber \& Ross, 1975) and in the regulation of the hypothalmic-pituitary axis (Martensz, Baird, Scaramuzzi \& Van Look, 1976). Short (1962) isolated androgens from the bovine ovary and Shemesh \& Hansel (1974), Kanchev, Dobson, Ward \& Fitzpatrick (1976) and Kanchev \& Dobson (1976) noted increases in peripheral testosterone concentrations before oestrus and corpus luteum (CL) regression, but no relationships were found with androstenedione during the oestrous cycle of the cow. Peterson, Fairclough \& Smith (1978) found no change in testosterone values before CL regression or at oestrus in the cow. Relationships of dehydroepiandrosterone are totally unknown in the cow although dehydroepiandrosterone may be important in bovine ovarian steroidogenic pathways (Lacroix, Eechaute \& Leusen, 1974). We have therefore examined the secretion of androstenedione, testosterone and dehydroepiandrosterone from the ovary of beef cows.

\section{Materials and Methods}

\section{Animals}

The 12 Hereford and Angus cows used were confirmed as having normal oestrous cycles. A cannula was placed into the ovarian vein on the side ipsilateral to the CL and into the carotid artery

* Present address: USDA Meat Animal Research Center, P.O. Box 166, Clay Center, Nebraska 68933, U.S.A. 
(via the facial artery; Wise, Caton, Thatcher, Barron \& Fields, 1982). Blood samples were then collected during the oestrous cycle. The ovarian vasculature was closely observed for the location of the ovarian-uterine vein anastomosis so that the ovarian cannula was not inserted into or beyond this area. Patency of the ovarian vein cannula was generally limited to 5-6 days. It was not possible to study an individual animal throughout the entire period but the records for the different cows do overlap.

Ovarian blood flow was monitored in 6 animals as described by Wise et al. (1982). This, in conjunction with the sampling of ovarian vein and peripheral arterial blood, permitted the calculation of total androgen release from the ovary [(ovarian vein concentration - arterial concentration) $\times$ (ovarian blood flow)].

The blood samples $(10 \mathrm{ml})$ were collected four times daily $(06: 00,12: 00,18: 00$ and 24:00 h) into slightly greased, heparinized syringes. The blood was centrifuged and the plasma stored at $-20^{\circ} \mathrm{C}$ until analysed for steroids.

\section{Extraction and chromatography}

To each $1 \mathrm{ml}$ ovarian vein plasma $\left[1,2,6,7-{ }^{3} \mathrm{H}\right]$ androstenedione $(\mathrm{sp}$. act. $114 \mathrm{Ci} / \mathrm{mmol}),[1,2,-$ $\left.{ }^{3} \mathrm{H}\right]$ dehydroepiandrosterone (sp. act. $58 \cdot 6 \mathrm{Ci} / \mathrm{mmol}$ ) and $\left[1,2,6,7-{ }^{3} \mathrm{H}\right]$ testosterone (sp. act. $98 \cdot 8$ $\mathrm{Ci} / \mathrm{mmol}$ ) were added (3500 d.p.m. of each) to determine procedural losses. All radioactive steroids were obtained from New England Nuclear, Boston, Massachusetts. Each sample was extracted twice with $10 \mathrm{ml}$ freshly distilled diethyl ether. Aqueous phases were frozen in liquid nitrogen, permitting the ether to be decanted and subsequently dried under nitrogen at $40^{\circ} \mathrm{C}$. The residue was applied to a $1 \times 25 \mathrm{~cm} \mathrm{LH}-20$ column with cyclohexane-benzene-methanol (90:25:5 by vol.), and eluates were collected in 2-ml aliquants (Wise et al., 1982).

Androstenedione was measured in 4-ml samples of carotid arterial plasma following addition of 1800 d.p.m. $\left[1,2,6,7-{ }^{3} \mathrm{H}\right]$ androstenedione and double extraction with $15 \mathrm{ml}$ ether. A $0.5 \times 7 \mathrm{~cm} \mathrm{LH}$ 20 column with a cyclohexane-benzene-methanol $(90: 5: 5$ by vol.) solvent system was used to effect separation of the androstenedione (Wise et al., 1982).

\section{Hormone assays}

Androgen concentrations were measured by radioimmunoassay as described by Buster \& Abraham (1972) for androstenedione (antiserum S-1557 No. 2), Coyotupa, Parlow \& Abraham (1972) for dehydroepiandrosterone (antiserum S-1502 No. 7) and Abraham \& Chakmakjian (1973) for testosterone (antiserum S-741 No. 2). The antisera originated in sheep and were raised against androstenedione-3-oxime-human serum albumin, dehydroepiandrosterone-3 $\beta$-mono-hemisuccinate-human serum albumin and testosterone-3-oxime-human serum albumin antigen. The crossreaction values (percentage binding at $50 \%$ displacement) were $25 \%$ for the dehydroepiandrosterone and 3\% for testosterone with the androstenedione antiserum, $12 \%$ for androstenedione and $<0.01 \%$ for testosterone with the dehydroepiandrosterone antiserum and $<0.1 \%$ for androstenedione and $<0.06 \%$ for dehydroepiandrosterone with the testosterone antiserum. Cross-reactivity with other steroids was $<1 \%$.

The average ( $\pm \mathrm{CV}$ ) recovery of each ${ }^{3} \mathrm{H}$-labelled steroid added to plasma as an internal standard was $86 \% \pm 0.23$ for androstenedione, $85 \% \pm 0.01$ for dehydroepiandrosterone and $68 \%$ $\pm \mathbf{0 . 2 3}$ for testosterone.

Known amounts of steroids were added to duplicate plasma samples $(1 \mathrm{ml} \mathrm{each})$ from an ovariectomized cow, and the steroids were extracted, chromatographed and measured by radioimmunoassay so that the accuracy and reproducibility of the method could be determined. The pooled intra-assay coefficient of variation when $100,200,500$ and $1000 \mathrm{pg}$ androgen were added were $10.9 \%(n=39)$ for androstenedione, $8.8 \%(n=27)$ for dehydroepiandrosterone and $8.9 \%(n=$ $28)$ for testosterone. The pooled interassay coefficients of variation were $11 \cdot 5(n=4), 9 \cdot 8(n=3)$ 
and $7 \cdot 5 \%(n=3)$ respectively. The sensitivity of the assays, defined as the smallest amount detectable from 0 , was $15 \mathrm{pg} / \mathrm{ml}$. Steroid concentrations were determined by a linear regression calculated from the log-logit transformation of known standards.

\section{Statistical analysis}

Data were analysed by split-plot least-squares regression as described by Barr \& Goodnight (1976). An analysis of spike release of hormones as an index of ovarian secretory activity was conducted by $\chi^{2}$ tests. Hormonal levels exceeding the overall mean plus two standard deviations calculated from all experimental animals was considered a spike of steroid released from the ovary by that animal (method of Brandt as described by Batson, 1956).

Changes in ovarian and peripheral androgens were analysed by least-squares to detect possible differences between groups of animals with or without blood flow transducers among the four periods $(06: 00,12: 00,18: 00$ and $24: 00 \mathrm{~h})$ monitored within day, and among days before and after functional luteolysis. No differences in patterns of androgen concentrations in the ovarian vein or ovarian release were detected between animals with or without blood flow transducers.

To overcome differences in oestrous cycle lengths, all responses were adjusted to Day -4 , Day 0 being the day of expected oestrus. Day -4 was identified when two successive peripheral blood samples contained $<1 \mathrm{ng}$ progesterone/ml (Wise et al., 1982), indicating functional luteal regression. No attempts were made to detect oestrus for fear of damage to the ovarian vein catheters and blood flow transducers; however, any cyclic phenomena observed were supported by (1) determination of ovarian structural changes by palpation per rectum, (2) observed behavioural oestrus when the cow was placed with other animals after removal of the blood flow transducer and (3) a cyclic decline and increase in ovarian blood flow and progesterone levels associated with ovulation and CL renewal (Wise et al., 1982).

\section{Results}

\section{Ovarian vein androgen concentrations}

As shown in Text-fig. 1 and Table 1, androgens tended to increase as the CL regressed although statistical regression analysis of androgen changes over days detected no significant changes. There

Table 1. Concentrations (arithmetic mean and range in parentheses) of androgens in the ovarian vein blood of cyclic cows (Day $0=$ day of expected

oestrus)

\begin{tabular}{|c|c|c|c|c|c|c|c|}
\hline \multirow{2}{*}{$\frac{\text { Day }}{-17}$} & \multirow{2}{*}{$\begin{array}{c}\begin{array}{c}\text { No. of } \\
\text { samples }\end{array} \\
4\end{array}$} & \multicolumn{2}{|c|}{$\begin{array}{l}\text { Androstenedione } \\
(\mathrm{ng} / \mathrm{ml})\end{array}$} & \multicolumn{2}{|c|}{$\begin{array}{l}\text { Dehydroepiandrosterone } \\
\text { (ng/ml) }\end{array}$} & \multicolumn{2}{|c|}{$\begin{array}{l}\text { Testosterone } \\
\text { (ng/ml) }\end{array}$} \\
\hline & & $2 \cdot 5$ & $(3 \cdot 7-7 \cdot 8)$ & 0.35 & $(0.16-0.48)$ & 0.7 & $(0 \cdot 3-1 \cdot 6)$ \\
\hline-16 & 9 & 2.6 & $(0 \cdot 3-8 \cdot 1)$ & 0.26 & $(0.01-0.91)$ & 0.5 & $(0 \cdot 0-1 \cdot 5)$ \\
\hline-15 & 9 & 4.6 & $(0.4-20.0)$ & 0.46 & $(0.05-2.00)$ & 0.6 & $(0 \cdot 1-1 \cdot 9)$ \\
\hline-14 & 8 & 3.6 & $(0.3-11.0)$ & 0.50 & $(0 \cdot 05-1 \cdot 10)$ & 0.9 & $(0 \cdot 0-2 \cdot 2)$ \\
\hline-13 & 9 & 6.9 & $(0.4-13.0)$ & $3 \cdot 20$ & $(0 \cdot 06-24 \cdot 00)$ & 1.7 & $(0 \cdot 1-8 \cdot 5)$ \\
\hline-12 & 14 & $3 \cdot 3$ & $(0.2-8.5)$ & 0.63 & $(0.03-1.90)$ & 1.5 & $(0 \cdot 2-4 \cdot 3)$ \\
\hline-11 & 13 & $5 \cdot 4$ & $(0.4-26.7)$ & 0.29 & $(0.04-0.76)$ & 0.9 & $(0 \cdot 2-1 \cdot 7)$ \\
\hline-10 & 9 & $7 \cdot 7$ & $(1 \cdot 6-26 \cdot 6)$ & 0.56 & $(0 \cdot 18-1 \cdot 30)$ & 1.5 & $(0 \cdot 3-3 \cdot 4)$ \\
\hline-9 & 9 & 7.5 & $(0 \cdot 4-24 \cdot 5)$ & 0.98 & $(0 \cdot 21-2 \cdot 20)$ & $2 \cdot 1$ & $(0.6 .9 \cdot 4)$ \\
\hline-8 & 18 & $10 \cdot 4$ & $(1.4-29.5)$ & 0.84 & $(0 \cdot 12-2 \cdot 20)$ & 3.6 & $(0 \cdot 5-17 \cdot 3)$ \\
\hline-7 & 17 & 8.4 & $(0.8-18.4)$ & 0.78 & $(0 \cdot 15-2 \cdot 80)$ & $4 \cdot 1$ & $(0 \cdot 2-38 \cdot 5)$ \\
\hline-6 & 18 & $12 \cdot 1$ & $(1.0-39 \cdot 1)$ & 1.80 & $(0.48-9.20)$ & 3.2 & $(0 \cdot 3-7 \cdot 9)$ \\
\hline-5 & 13 & 9.9 & $(0.9-38.4)$ & $2 \cdot 10$ & $(0.13-6.50)$ & $4 \cdot 7$ & $(0 \cdot 1-10 \cdot 6)$ \\
\hline-4 & 11 & 9.7 & $(0.8-37.6)$ & 1.20 & $(0.01-10.50)$ & $2 \cdot 8$ & $(0.8-6 \cdot 6)$ \\
\hline-3 & 1 & 3.5 & & 0.13 & & 0.4 & \\
\hline
\end{tabular}



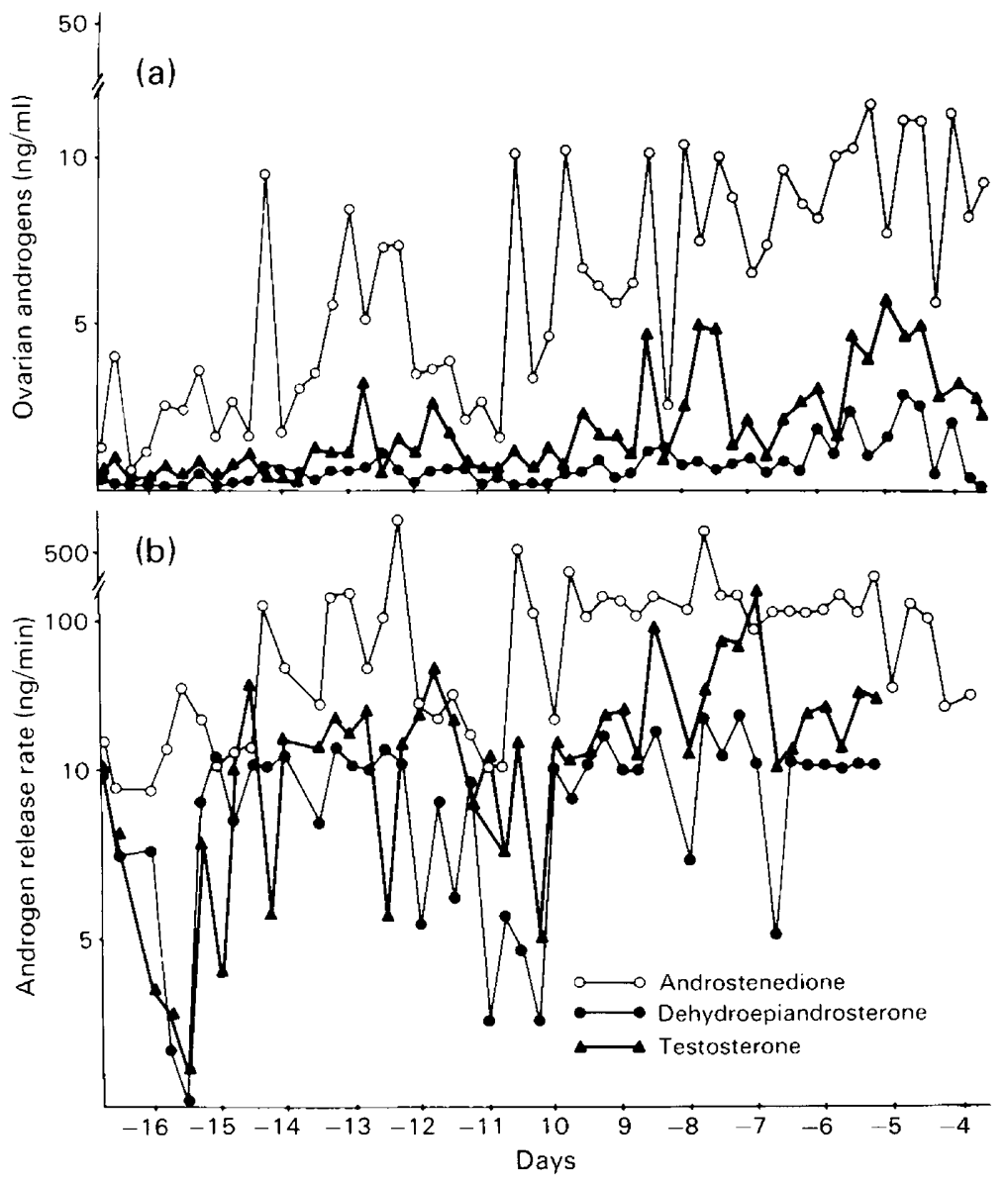

Text-fig. 1. (a) Concentrations of androgens in the ovarian vein of cows and (b) the release rate of androgens from the ovary (see text) during the oestrous cycle. See Table 1 for numbers of samples and ranges of values for (a). For (b), there were 2-11 observations per day.

were no differences in androgen levels between time periods within days. Within-animal correlations between androstenedione and dehydroepiandrosterone $(0 \cdot 26)$, androstenedione and testosterone $(0.24)$ and testosterone and dehydroepiandrosterone $(0.14)$ were detected $(P<0.05)$; but there were no relationships of androgens with ovarian blood flow or day $(P>0 \cdot 10)$. Decreases in ovarian blood flow were associated with $\mathrm{CL}$ regression (from 25 to $<8 \mathrm{ml} / \mathrm{min}$ ), and limited blood sampling and androgen analysis from the ovarian vein after regression of the CL.

Ovarian androgens displayed wide fluctuations within day (Text-fig. 1a). The sampling period was divided into four intervals (Days -17 to $-14,-13$ to $-9,-8$ to -4 and -3 to +1 for $\chi^{2}$ analysis of peaks of secretion. Although the majority of androgen peaks were found during Days -8 to -4 (1-4 days before $C L$ regression), $\chi^{2}$ analysis with orthogonal comparisons failed to detect significant differences among any of the periods.

\section{Peripheral androstenedione}

Androstenedione concentrations tended to increase 1-4 days before luteal regression (Table 2) and on Day 0 . However, there were no significant day trends when androstenedione concentrations 
Table 2. Concentrations (arithmetic mean and range in parentheses) of androstenedione in peripheral arterial blood of cyclic cows (Day $0=$ day of expected oestrus).

\begin{tabular}{|c|c|c|c|c|c|c|c|}
\hline \multirow{2}{*}{$\frac{\text { Day }}{-17}$} & \multirow{2}{*}{$\begin{array}{c}\begin{array}{c}\text { No. of } \\
\text { samples }\end{array} \\
4\end{array}$} & \multicolumn{2}{|c|}{ Androstenedione $(\mathrm{pg} / \mathrm{ml})$} & \multirow{2}{*}{$\frac{\text { Day }}{-7}$} & \multirow{2}{*}{$\frac{\begin{array}{c}\text { No. of } \\
\text { samples }\end{array}}{27}$} & \multicolumn{2}{|c|}{ Androstenedione $(\mathrm{pg} / \mathrm{ml})$} \\
\hline & & $9 \cdot 0$ & $(7 \cdot 0-13)$ & & & $160 \cdot 5$ & $(4 \cdot 0-169)$ \\
\hline-16 & 9 & $29 \cdot 0$ & $(2 \cdot 0-152)$ & -6 & 30 & $109 \cdot 0$ & $(3 \cdot 0-660)$ \\
\hline-15 & 9 & $35 \cdot 0$ & $(4 \cdot 2-91)$ & -5 & 31 & $56 \cdot 0$ & $(5 \cdot 0-315)$ \\
\hline-14 & 9 & $26 \cdot 7$ & $(2 \cdot 1-108)$ & -4 & 31 & $126 \cdot 0$ & $(4 \cdot 0-940)$ \\
\hline-13 & 10 & $20 \cdot 8$ & $(6 \cdot 0-67)$ & -3 & 15 & $34 \cdot 0$ & $(0 \cdot 4-100)$ \\
\hline-12 & 13 & $21 \cdot 6$ & $(5 \cdot 0-70)$ & -2 & 14 & $51 \cdot 5$ & $(2 \cdot 0-175)$ \\
\hline-11 & 13 & $48 \cdot 0$ & $(2 \cdot 0-352)$ & -1 & 12 & $28 \cdot 8$ & $(2 \cdot 0-55)$ \\
\hline-10 & 14 & $48 \cdot 7$ & $(0 \cdot 3-300)$ & 0 & 10 & $153 \cdot 0$ & $(7 \cdot 0-1270)$ \\
\hline-9 & 16 & $41 \cdot 7$ & $(10 \cdot 0-119)$ & +1 & 9 & $24 \cdot 7$ & $(5 \cdot 0-57)$ \\
\hline-8 & 25 & 79.0 & $(0 \cdot 3-382)$ & +2 & 10 & $31 \cdot 0$ & $(4 \cdot 0-97)$ \\
\hline
\end{tabular}

were analysed by statistical regression analysis or for spike releases. Androstenedione concentrations in peripheral plasma were positively correlated with those in ovarian vein blood plasma $(r=0 \cdot 17 ; P<0.05)$, but no relationships were detected for time within day or ovarian blood flow.

\section{Ovarian release of androgens}

Androgen release rates from the ovary were monitored by the establishment of ovarian venous catheters and ovarian arterial blood flow transducers $(n=6)$, i.e. [(ovarian vein concentration peripheral concentrations) $\times$ ovarian blood flow (Text-fig. 1 b)] for androstenedione and (ovarian vein concentration $x$ ovarian blood flow) for dehydroepiandrosterone and testosterone. There were no within-time or among-day trends for release of any of the hormones. Most peaks of release were during Days -8 to -4 , but only the value for testosterone differed among periods (Days -12 to $-9<$ Days -9 to $-4 ; P<0.05)$ in number of spikes.

\section{Discussion}

Of the androgens measured in this analysis, androstenedione was quantitatively the highest and dehydroepiandrosterone the lowest. Since Lacroix et al. (1974) showed that the predominant invitro pathway of follicular oestrogen synthesis in the cow may be via the $\Delta^{5}$ pathway (pregnenolone through dehydroepiandrosterone to oestrogens) the low levels of dehydroepiandrosterone noted in this study may be due to an active metabolism of this substrate to oestrogens and a pooling of other androgens.

Shemesh \& Hansel (1974) and Kanchev \& Dobson (1976) reported patterns of peripheral testosterone in the cow that were similar to patterns of oestradiol. Since androgens are precursors of oestrogens, changes in ovarian androgen concentrations may reflect periods of follicular development during the bovine oestrous cycle. The rise and fall of ovarian androgens among days of the oestrous cycle may be indicative of 'waves' of follicular growth (Thibault, 1977); however, statistical regression analysis for day trends revealed no predictable changes among days in the present study. The rapid fluctuations (Text-fig. 1) in ovarian androgens suggested surges of release into the ovarian vein over a short duration similar to the peripheral androstendione patterns noted by Kanchev \& Dobson (1976) and Peterson et al. (1978). The dynamic changes in ovarian androgens during the oestrous cycle noted in this study may be more compatible with the data of Choudary, Gier \& Marion (1968) who stressed that follicular development was continuous and independent of specific days of the oestrous cycle. 
The highest levels of testosterone in the cyclic cow and ewe are during the luteal phase and just before CL regression (Kanchev et al., 1976; Hoffman \& Rattenberger, 1977; Herriman, Harwood, Mallinson \& Heitzman, 1979). We found differences for the release of testosterone on Days -8 to -4 and Days -13 to -9 : the significant increases in spikes of testosterone release before $\mathrm{CL}$ regression concur with the increases noted by Kanchev et al. (1976) in peripheral testosterone levels during the oestrous cycle.

The origin of bovine ovarian androgens is unknown. Shemesh, Hansel \& Concannon (1975) reported that the bovine CL at Day 12 of the cycle contained appreciable amounts of testosterone $(2.6 \mathrm{ng} / \mathrm{g}$ tissue) and that prostaglandin $\mathrm{F}-2 \alpha$ added to in-vitro incubation systems stimulated testosterone synthesis. Increases in ovarian testosterone within the 4-day period before CL regression may be of luteal origin, indicating a change in CL steroid metabolism, possibly induced by prostaglandin F-2 $\alpha$ at the time of $\mathrm{CL}$ regression. The possibility of uterine prostaglandin F- $2 \alpha$ coordinating follicle growth and atresia with the fate of the CL through luteal androgens requires further elucidation.

This work is Florida Agr. Exp. Sta. Journal Ser. No. 2641 and was supported by a grant from NIH R01-HD-05659.

\section{References}

Abraham, G.E. \& Chakmakjian, Z.H. (1973) Serum steroid levels during the menstrual cycle in a bilaterally adrenalectomized woman. J. clin. Endocr. Metab. 37, $581-587$.

Bar, A.J. \& Goodnight, J.H. (1976) A User's Guide to the Statistical Analysis System. North Carolina State University, Raleigh.

Batson, H.C. (1956) Applications of factorial $\chi^{2}$ analysis to experiments in chemistry. Proc. 10th Ann. Meet. Am. Soc. Quantitative Chemist, pp. 923.

Buster, J.E. \& Abraham, G.E. (1972) Radioimmunoassay of plasma dehydroepiandrosterone. Anal. Lett. 5, $203-215$.

Choudary, J.B., Gier, H.T. \& Marion, G.B. (1968) Cyclic changes in bovine vesicular follicles. J. Anim. Sci. 27, 468-471.

Coyotupa, J., Parlow, A.F. \& Abraham, G.E. (1972) Simultaneous radioimmunoassay of plasma testosterone and dihydrotestosterone. Anal. Lett. 5, 329340 .

Herriman, I.D., Harwood, D.J., Mallinson, C.B. \& Heitzman, R.J. (1979) Plasma concentrations of ovarian hormones during the oestrous cycle of the sheep and cow. J. Endocr. 81, 61-64.

Hoffman, B. \& Rattenberger, E. (1977) Testosterone concentrations in tissue from veal calves, bulls and heifers and in the milk samples. J. Anim. Sci. 45, 635641.

Kanchev, L.N. \& Dobson, H. (1976) Plasma concentration of androstenedione during the bovine oestrous cycle. J. Endocr. 71, 351-354.

Kanchev, L.N., Dobson, H., Ward, W.R. \& Fitzpatrick, R.J. (1976) Concentrations of steroids in bovine peri- pheral plasma during the oestrous cycle and the effect of betamethasone treatment. J. Reprod. Fert. 48, 341345.

Lacroix, E., Eechaute, E. \& Leusen, I. (1974) The biosynthesis of estrogen by cow follicles. Steroids 23, 337356.

Louvet, J.R., Harman, M., Schreiber, J.R. \& Ross, G.T. (1975) Evidence for a role of androgens in follicular maturation. Endocrinology 97, 366-372.

Martensz, N.D., Baird, D.T., Scaramuzzi, R.J. \& Van Look, P.F.A. (1976) Androstenedione and the control of luteinizing hormone in the ewe during anoestrus. $J$. Endocr. 69, 227-237.

Peterson A.J., Fairclough, R.J. \& Smith, S.T. (1978) Radioimmunoassay of androstenedione and testosterone in cow plasma at the time of luteolysis and oestrus. J. Reprod. Fert. 52, 127-129.

Shemesh, M. \& Hansel, W. (1974) Measurement of bovine plasma testosterone by radioimmunoassay (RIA) and by a rapid competitive protein binding assay (CPG). J. Anim. Sci. 39, 720-724.

Shemesh, M., Hansel, W. \& Concannon, P.W. (1975) Testosterone synthesis in the bovine corpus luteum. Biol. Reprod. 13, $490-493$.

Short, R.V. (1962) Steroids present in the follicular fluid of the cow. J. Endocr. 23, 401-411.

Thibault, C. (1977) Are follicular maturation and oocyte maturation independent processes? J. Reprod. Fert. 51, 1-15

Wise, T.H., Caton, D., Thatcher, W.W., Barron, D.H. \& Fields, M.J. (1982) Ovarian function during the estrous cycle of the cow : ovarian blood flow and progesterone release rate. J. Anim. Sci. 55, 627-637. 